14. Ubtoff (second case). VIrch. Festschrif, Berlin, 1891, Band xi., D. 423.

15. Holden. Arch. of Ophthel., Nev York, 1892, Xil., 1, p. 70.

10. Scholtz (second case). Arch. f. Augenhelly., 1893, IxyL, ID; Trans. Arch. of Ophthal., New York, 1894, xxill. 2, p. 109 .

17. Kamocil. Arch. $f$ Angenheitk, 1893, 1xviL; Arch. of Ophthal., New York, 1894, rol Ixill., 1 and \& p. 105 .

18. Noger Trans, Am. Ophthal. Soc., 1896 and 1897 , vol. vil. p. 528.

19. Abelsdorf. Arcb. f. Angenheilk, xxxili. p. 84; Areh. of Opbthal, New Yark, 1897, Ixvi., 2, p. 238 .

20. Matheirson. Reparted at the meeting of the Brtish Yedical Association, Montreal, 1897. Ref. to case by Mrarshalt (eerer. 21). Personal communication.

21. Mraschall. Royal Ophthal. Hosp. (London) Reports, 189i, riv., 3. p. 115.

22. Kaemmerer. Corrbl des allg. Aerzt. Vereins, von Thmofigen, 1ss8, 3, p- 62

23. Wagenman. Corrbl. des allg. Aerzt. Vereins, von Thnringen, 1898, 2 p. 31 .

24. Ln Grange. Areb. d. Ophthalmologie, 1893, xvili, 1, p. 30 .

35. Rowan. Trans. Ophthal. Soc., Untted Kingdom, 1899, vol. xix., p. 103.

26. de Schweinitz and Steele. Proceedlugs of the Patbological Soclety of Philsdelphis, Januntr 1899, N. S., vol. It, Nio. S, p. 33.

27 , Bentzon. Hospltals-Tidente, 1900, ix., 4.

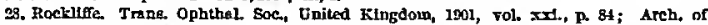
Ophthal., New York, 1902, xxr1, $3, \mathrm{p}, 487$.

9. Ch. Guende. Rec. d'Ophthatmologte, 1890, xil., 3, p. 395 .

30. Wagaer. Jeber Metast. Aderhanttumor. Published bs G. Schroeter, Halle, 2891.

3t. Samelsobn. Dentsch. med. TYochenscbrift, 1891, xrit, 30, p. 927.

\$2 Schoebl. Norris and Otrer's System nf Disenses of the Eje, Philadelphis, 1698, vol. 11i. p.536.

33 Dittich. Pras. Vterteljabrschrift, rol zil.

31. Krabm. Zebnders klla Mroubl., x., p. 103.

35. Elschnig. Arch $f$ Augeobelk., xxilf p. 149; Arch. of Opbthal, New York, vol xx, p. 370 .

35. Holden. Arch. of Oph that, Aiew York, $2 x 21,5$, p. 427.

37. Grifith. Horris and Oltrer's S5stem, Philadelphla, 1898, vol. $13 i$, p. 375.

35. Siarshall. Traos. Opbthal. Soc. Jufted Kingdom, 1896, Iri., p. 155.

39. Branhall. Rojal Ophtbal. Hosp. (London) Reports, 1899, vol, I7., p. 57.

40. Wood and Pusey. Arcb. of Ophthal., New York, 1902, Ixx., 4, p.523.

41. Braemser. Inaug. Dissert. Bertin, 1850 ; Areb. of Opbthed, Niew York, Iir., p. 185.

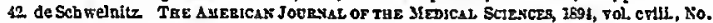
2, D. 193.

43. Fuchs. Das Sarrom des Uvealtractus, Wien, 1882.

4. Bull. Trinsactions of the American Ophthalmic Soclety, 1896, p. 496.

\title{
A REPORT OF CASES OF AN FAIIA, WITH OBSERVATIONS UPON THEIR SYMPTOMS AND MORPHOLOGY OF THE BLOOD.
}

BY J. Alison Scorr, M.D.,

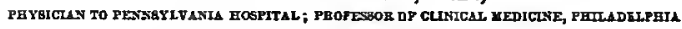
POLTCLIMIC HOSTITAL.

I DESRE to report the folloring eases, which occurred during the past winter in my service at the Pennsylvania Hospital :

Severe Secondary Anamia Due to Repeated Metrorrhagia. Lizzie R., aged thirty years, white, married, housevife, born in Russia. Father died from unknown cause; mother died in confinement; has one sister in good health; lost one brother in childhood. 
Past History. Has been a healthy woman. Has one child, aged seven yenrs. Ten weeks nfter the hirth of this child nn infected right ovnry was removed. Menstruntion since this operation has heen regular. After the operatinn she never recnvered her former color. The present illness hegnn two weeks ago, with constant but rather scanty bleeding from ths ragina. She bas bnd slight nose-hleed, with pain in the abdomen, beadnche, dizziness, ringing in the ears, and slight cough. She states thnt she has becoms very pale during this time. Bowels are constipated.

Admitted to the Pennsylrania Hospital MLarch 5, 1902 (hospital No. 4014).

Physical Examinalion. She is a well-nourished romnn. Face seems puffy; pupils equnlly dilated. Face nnd skin pnllid, not lemon-tinted; mucous membranes and nails practically colorless. The radial pulse quick, of fair volume, and very compressible. Tongue pale, moist, with rather thick, yellowish cnat; no venous phenomena. The lungs are normal. Visible cardiac impulse in the fourth interspace, $10 \mathrm{~cm}$. froin mid-sternum. On nuscultation, a soft, hlosiag, systolic murmur, hest heard in the third iaterspace, and nlso present at the pulmoary cartilage. Abdomea round, globular; nowhere teader. Liver and spleen normal ia eize. Vaginal examination: Neither ovary is felt; the cervix is rather soft, the uterus slightly incressed ia size. A small amount of dark hrown vaginal diseharge is present. The urine : Specific gravity 1014 ; acid; costains neither alhumia nor sugar, and no casts. The blood sborred: Erythrocytes, 910,000; leucocytes, 5300; hismoglobia, 17 per ceat. The differential count sbowed: Polyauclears, 80 per ceat.; small lymphocytes. 13.6 per ceat.; transitionals and taononuclears, 2 per ceat.; eosiaophiles, 4 per ceat.; uaidea tified cells, $t$ per ceat. The unideatified cells are polsnuclears without graaules, and pale stainiag nuclei. The corpuscles are uausually small; slrow no polychromatophilia; no megalohlasts found. Three normoblagts were fouad during the examination of several slides. The patient had a temperature oa admission of $100.2^{\circ} \mathrm{F}$., which rose to $102^{\circ} \mathrm{F}$. the following day. During the next seven days it gradually fell to normal.

She was put upon peptomangan, 1 ounce four times a day, with Fowler's solutioa, 3 drops, and adrenal extract, 1 graia, three times a day. She tras giren a tluid diet and 4 ounces of gelatin, twice a day. Her improvement in $n$ week's time was remarkable, the blood count rnpidly rising -erythrocytes, 2,630,000; leucocytes, 4600; hremoglohin, 35 per cert. During this stage the differential count showed a slight diminution in the polynuclear leucocytes, with an increase in the small lymphocytes. One week later the erythrocytes had risen to $3,392,000$; leucocytes, 3800 ; hanoglohin, 62 per cent. Since her admission tn the bospital there has been no exidence whaterer of uterine hemorrhage or hleeding from any other source. She complains mainly of headuche, thirst, and rague ahdominal pains. Discharged at her orn request on the $22 \mathrm{~d}$ of Mirch.

This case shows the rapid and serere anxemin induced by repeated small hemorrhages. The woman, who was rather a plump specimen, appeared as white as alahaster. Blood examination did not show the leucocytosis which is common after losses of large amounts of hlood. 
During convalescence the nnmber of lymphocytes and normoblasts was not disproportionate, as some ohservers have noted; nor was there marked change in the size or form of the red cells.

Severe Secondary Ancemia, Cantse not Ascertained, followed by Relapse and Death. Adolph K., aged fifty-four years, white, married, born in Germany. Family history not important.

Previous History. Healthy man; no severe sickness in life, no venereal disesse; used beer very moderately. Present illaess began several months ago with increasing pallor and weakness, shortness of breath, and swelling of the reet. This pallor was preceded by a diarrhœa of several weeks' duration. He was admitted to the hospital on Octoher 24th (hospital No. 2132).

Physical Examination. He is a large-honed, fairly rell-nourished man. Rather waxy appenrance on face and skin, not lemon-colored. Sclera pearly; mucous membranes and nails rery pallid; no pigmentation of skin. Comparatively few teeth remain in eitber jaw; gums shrurken, not ulcerated. Lungs normal. Heart normal except hæmic murmur at apex. Tbe abdomen negative, witb the liver and spleen normal ia size. Slight cedema present on the dorsum of the feet and over tbe tibia. Blood: Hæmoglobin, 25 per cent.; erytbrocytes, $2,380,000$; leucocytes, 6500 ; differential count 250 : polynuclears, 76 per cent.; small lymphocytes, 16.8 per cent.; transitionals and large monoauclears, 5.4 per cent.; eosinophiles, 8 per cent. Tbe urine ras normal in color; negative on chemical and microscopic examination. Examiaation of the stools revenled no intestinal parasites or eggs. Examination of a test-meal showed: Hydrocliloric acid, 2 per cent. ; total acidity, 40 per cent.; no lactic acid; pepsin present.

He remained in tbe hospital fifty-eight days, with a ratber rapidly increasiag red count. Thus by October 29 th the erythrocytes were $3,987,000$, the leucocytes 8650 , with hæmoglobin 43 per cent. At this time there was a decided increase in the small lymphocytes, wbich reached 22 per cent., wbile the polynuclears dropped to 64 per cent. This hlood state was not constant, for before his discbarge the moannuclears agaia dropped to 11.6 per cent., the polynuclears rising to 76 per ceat. He was permitted to return to his home on November 20 th, with sn erytbrocyte cout of $4,443,750$, and a hemoglobin percentage of only 50 .

The improvement in this case was extremely rapid. He gained in color and in strength under the use of Blaud's pills. His blood showed but moderate poikilocytosis, with no macrocytes, while microcytes and elongated forms were fairly nnmerous. No nuclented reds were found, nor was there adequate cause ever discovered for the intense anamia. The diarrbea which was present two months hefore admission may bave been its basis, tbough there was no evidence of hlood is his stools at any time during his stay in the hospital.

I leara as I write these notes that he was admitted within a few days to the wards of my colleague, Dr. Lewis, having had a relapse, which hegan ahout February. His blood count upon readmission was: Hremoglohin, 17 per cent. ; erythrocytes, 2,140,000; leucocytes, 8600. He was extremely weak. In a few days the hæmoglohin had dropped to 13 per cent., with erythrocytes to $1,836,000$. The eyes, examined hy Dr. Harlan, show fields very pale, bloodvessels pale, almost invisible, 
hut no hemerrhages. The patient was permitted to leave the hospital hecause of extreme homesickness, and I learn he died twenty-four hours later. The differential count in this case at this time showed a slight polynuclear excess -80 per cent. ; no nucleated reds were fouad.

It is possihle that this case may exemplify a severe type of secondary anxmia which rapidly hecame pernicious.

Secondary Anamia Due to Cancer of the Stomach. Margaret H., white, aged fifty-six years, domestic; mother of two children; no ohtainahle family history. Was at work one week hefore admission. Three weeks hefore admission is said to have had trouhle with her stomach for several days, compeling her to stop work. Admitted to the hospital Fehruary 1, 1902 (hospital No. 3603).

Physical Examination. A small, rather stocky woman, somewhat irrational. Very few teeth in either jaw; no ulceration of gums. Face and hody rather lemon-yellow in color; the mucous membrames and nails colorless. Pulse small, rapid, compressible. One or two small, hluish discolorations upon the arm; no evidence of hemorrbage elsewhere either in the mucous membrases or the skin. Lungs normal. Heart : systolic apical murmur. Ahdomen soft; no mass palpable; winces somewhat on palpation in the epigastric region. No enlarged superficial lymphatic glands. Urice light yellow; contains no alhumin or sugar. Blood: Hxmoglohia, 20 per cent.; erythrocytes, 1,000,000; leucocytes, 18,000. Differential count: Decided polynuclear excess, 90 per cent.; moderate poikilocytosis present; numerous nucleated reds; 125 seen in couuting $\mathbf{5 0 , 0 0 0 ~ l e u c o c y t e s , ~ m o s t l y ~ n o r m o h l a s t s . ~}$

In twenty-four hours the patient was decidedly worse; semiconscious; had romited material, which, unfortunately, was not seen hy the resideat. Pulse imperceptihle, though the henrt continued to beat for trenty-four hours loager. Died February 4th. Autopsy showed a small colloid cancer, ahout $8 \mathrm{~cm}$. in diameter, infiltratiug the posterior wall of the stomach near the lesser curvature. There was slight involvement of the lymphatic glands behiud the stomach and the herd of the pancreas.

This case shows how numerous nucleated red cells may hecome in the peripheral blood in secondary anxmia. Had this woman been conscious, and had an examination of the gastric contents been feasible, the diagnosis of carcinoma would have heen made with some certainty. In pernicious anæmia a terminal leucocytosis is common. The fact, however, that the -majority of nucleated cells were normohlasts is an important factor in the diagnosis hetween the secondary anamia due to cancer and pernicious anxmia. The cancer here was amall and quite recent, and was prohahly not entirely responsihle for the very severe grade of anmmia present in this case; in fact, these cases at times show the typical hlood picture of pernicious anzemia.

Chlorosis, with Frequent Relapse and Obstinate Cardiac Synptoms. Maggie M., aged nineteen years, white, single, horn in Ireland. Family history good, though one sister is said to be anæmic. 
Past History. Menstruated at sixteen years; came to the United States when seventeen. Since arrival here has menstruated hut four times. One year ago spent nine weeks in the University Hospital, with illness similar to present one; discharged much improved. Preseut illness : Sick for six months with headache, pain in both ovarian regions, weakness and shortness of hreath on exertion. She has become very pale, and complains of pain in the eyes, left side of the face, in the abdomen, and left arm. Is very nervous, with poor appetite; has a decided fondnes for candy and tea. Admitted to the bospital Fehrnary 9th (hospital No. 3669).

Physical Examination. Rather huxom but pallid Irish girl. Mucous membranes pale; tongue coated; pulse regular, rather full and hounding. Lungs normal. Heart overacts, with loud, booming first scund and systolic murmur at the hase. Increase in size of tbe left gide. Liver and spleen normal in size. Abdomen soft and flat; no gastroptosis. Vaginal examination reveals an unusually small, infantile uterus. Pelvis negative. Urine light yellow, acid; specific gravity, 1027 ; no albumin, no sugar; calcium oxalate. Blood: Hremoglohin, 38 per cent.; erythrocytes, $2,947,000$; leucocytes, 7000 ; differential count : polynuclears, 71.5 per cent.; small lymphocytes, 18.5 per cent. ; large mononuclears and transitionals, 7 per cent.; eoginophiles, 2 per cent.; mastzellen, 1 per cent. Blood cells are small and pale, with large central, non-staining portion. Moderate poikilocytosis; no polychromatophylia. Under forced diet, with large doses of Blaud's pills, combined with Eowler's solution and phosphate of eoda as a purge, her hlood condition improved slowly. On March 7th, hremoglobin, 52 per cent.; erythrocytes, 4,279,000. On May 9th, bxmoglohin, 60 per cent.; erythrocjtes 4,388,000. During all this time, however, the girl's heart would overact upon the slightest provocation. She complained constantly of smothering sensations ahout the heart, with palpitation. The use of purges to deplete the volume of blood; of local applications, such as the ice-bag over the heart; the ase of bromides internally, seemed to be of no avail whatever, and ahe left the hospital with a greatly improved blood condition, although still complaining of vague pains and guffering with palpitation of the heart from the slightest cauge.

This ense presents a combination of causes, one of which seems alone ahle to produce chlorosis. Tbus the disense is seen most frequently in girls ahout the menstrual developmental period; nostalgin is a frequent aid in its production. Dietetic errors-the abuse of tea, toast, and candy as hahitual diet -are freqnently met with. Its exact pathological basis is, however, difficult to find. Virchow's postulate-a hypoplasia of the lienrt, hloodvessels, and generative organs-will not hold, for many such conditions are found and no chlorosis exists. Hoffmann's and Sir Andrew Clarls'a view that ahsorption of toxins from tbe intestinal canal is tbe exciting canse does not cover all cases. It probahly is to he found in the functional derangement iu the hamoglohin manufacturing process of the bone-marrow.

Lloyd Jones also believes that the total volume of plasma is mnch 
iacreased in chlorosis. This will answer for the symptoms present in the ahove case-the palpitating, dilnted heart, with throhhing vessels.

Acute Progressive Pernicious Anomia ; Death ; Autopsy. MIaggie J., aged thirty-two years, white, married, housewife hy occupation; horn in Philadelphia. Family history: Fnther died with nsthma and mother of uterine hemorrhage; three hrothers died in infancy, from unknown causes.

Past History. Measles in childhood; hlindaess of the riglit cye (phthisical hall). When fifteen years of age was severely burned over the hack and chest and portion of the ahdomen; was eight months in recovering. Has had seven children, fre of rhom are living, ia good health. She states that before each child was born the skin became yellowish in color, and " the jaundice" disappenred after clildbirth. Present illness hegan three months ago, a short time prior to the birth of her last child, which was horu early in Fehruary, 1902. She complained of henrthura, with vomiting and constant eructation of gas, and a huraing sensation in the mouth. Two weeks after the hirth of ber child (February 22d) she had a large hemorrhnge from the howel, which was repeated upon the subsequent day, though accomparied with less hlood. For some weeks hefore admission she complained of sore gums. Her skin has heen yellow for four moaths, and she states that "the jaundice" has been nuch deeper hefore admission than at the preseat time.

Adnitted to the hospital March 18, 1902 (hospital No. 4181).

Phyrical Examination. She is a medium-sized, fairly well-nourished woman. Face and hody are lemon-yellow color. Conjunctiva distinctly yellowish. The toague is moist, pallid, with \&mooth and glazed surface; breath is fetid. There are ahout six froat teeth ia the upper jaw, while the few remainiag teeth are decayed. The lower jaw contains about seven front teeth; all the molars nre missing. The gums on hoth the upper and lower maxilln nre infumed and suppurating; there are ao hemorrhages of the mucous membrane. Cliest: The lungs are clear hoth in froat nnd hehind. Henrt of coraal size, though with soft, hæmic systolic nurmur at apex, and a similar hut louder murmur at the pulmonic and aortic cartilages. The abdonen is round and very flaccid. There is a slight dark browaish pigmentation over the margias of a large scar, which extends from the middle of the hack around to the front of the nhdomen. No mass is felt in the ahdomen; no glandular enlargement.

She remained in the hospital $\mathbf{a}$ little over four reeks. During the first two weeks there was considerable diarrhœa. On two occasions the stools contained a dark, gelatinous hlood clot. Her temperature has heen maintained hetween $100^{\circ}$ and $101^{\circ} \mathrm{F}$. The pulse soft, very compressible, averages 120. No evidence of dyspaca. Rather sleepy mental condition, with disinclination to nny exertion. Complains constantly of buraing in her mouth and thiret. No pains over joints or hones. Cultures taken from the mouth showed large numhers of streptococci pyogenes. On March 30th the stomach contents showed no free hydrochloric acid, no lactic acid; total acidity of 14 ; comhined hydrochloric acid 8 , or 0.0288 per cent. The knee-jerks present on hoth sides increased; no ankle clonus. During the last two weeks of her life the patient developed a diffuse cedema of the hack. The face 
hecame puffy and the limhs odematous. She cumplained of a constant ringing, of sounds, or music in her ears, and finnlly hecame totally deaf. There were no special cardiac or vaccular symptoms. Left eye-ground, examined hy Dr. Flarlan, showed a high degree of astigmatic hypermetropia; disks white; whole fundus pnle; venous hlood scarcely darker than arterial; extensive retinal hemorrhage, striated and non-striated.

No parasite or eggs were discovered in her stools. Urine (April 13 th) : 1260 c.c. in twenty-four hours; specific gravity, 1009; reddishyellow in color. Urea: 1.4 per cent. or $\mathbf{1 7 . 6}$ drachms in twenty-four hours; later examinations of urine showed lesser quantities of urea. No pathological urohilin was present; a large a mount of indican was, however, found. Two quantitative estimntes for indican gave 84 and 94 milligrammes for the twenty-four-hour specimen.

Blood: The dny of admission the hlood count was as follows: Hrmoglohin, 16 per cent.; erythrocytes, 744,000 ; leucocytes, 3700. A differential count showed : Polynuclear,, 78.2 per cent.; small Iymphocytes, 19.2 per cent; Inrge mononuclears and transitional cells, 1.2 per cent.; eosinopliles, 1.4 per cent. There was moderate poikilocytosis, with slight polychromasia. There were some megalocytes present; considerable endoglohular degeneration; two megalohlasts and two normohlasts were found. The red cells hecame fewer in numher as time went on, notwithstanding food and medicine and the hypodermic administration of arsenic.

The erythrocytes slowly fell until, during the first week of $A$ pril, the erythrocyte count was 268,000 , with leucocytes 5900 nnd hæmoglobin 3 per cent. The coagulation time of the hlood was six minutes; its specific gravity 1022. Blood cultures: All flasks remnined sterile after five daye. During the last week of life the womnn seemed drowsy and coinplained hut little. Skin dry; hair dry nad lustreless; the ear held up to the light was hloodless, and resemhled yellor parchment. Nails were hloodless. The condition of the gums was improved, and there was but slight odor to the breath. It was evident that she had lost flesh.

The last hlood count was made two days hefore death. Erythrocytes, 393,000; hamoglohin, 3 per cent. There was no terminal leucocytosis. The nutopsy showed widespread fatty degeneration of the organs, especinlly the heart nnd liver. There were in the ileum, several feet ahove the ileocrecal valve, two scars, entirely henled, with slight pigmentation ahout them. They seemed to he Peyer's patches. There was no involvement of other parts. Spleen and liver of normal size. Bone-marrov dark red, not fatty.

Microscopic Examination. Large numhers of megalocytes and of nucleated erythrocytes, the majority of them megalohlasts; in many the nuclei are undergoing fragmentation. There are comparatively few leucocytes present. The polynuclear leucocytes are almost entirely ahsent, the majority of the leucocytes heing myelocytes and lymphocytes; very few eosinophiles are present.

This case must, I think, he considered from both the clinical and pathological standpoint as one of peruicious ansmia $\longrightarrow$ - ne of the cases, however, in which pregnancy seems tn hnve heen the exciting cause. The symptoms, however, coincide well with that group of cases to which 
Huater bas recently called attention, namely, those with pyorrbcea and ulcerative gingivitis, with glazing of the tongae nod gastro-iatestinal symptoms. That the woman ahsorhed toxins from her iatestinal canal is evident. She had great iacrease in her iadican output, while there was no special evidence, excepting ber brematogeaous jaundice, in ber urine or elserwhere, of great hlood destruction. At first the blood examiaation showed but few megalohlasts and changes in size and shape. In the last two weeks of her life, however, nucleated cells became more ahundant, chiefly megalohlasts, though the differential count at no time showed a disproportion of lymphocytes. Of fre or six cases of pernicious ansmin seea during the last year, hut one cose preseated this increase in lymplocytes, which is aupposed to he characteristic of this disease. In this case I would call atten tion to the contiauous bigh bxmoglohia index, 1.78 to 2 per ceat. The rapid termination of this woman's life did not permit of the extensire chaoges in the morpholegy of the blood which are frequeatly observed in cases of much greater duratioa. The ahseace of polynuclear leucocytes in the honc-marrow and their apparent increase in the circulnting hlood is probahly accouated for by the supposition that in such an acute proceas there is still some honemarrow remaining unaffected which could manufacture polynuclear leucocytes. ( $I$ hope to report this case in greater detail in the future.)

Acute Lymphatic Leukainia, with Death and Aulopsy. Philip O. K., aged sixty-five years, white, married, painter by occupation. Family history of no interest.

Past Mistory. No serious illness in life except numerous attacks of pain and swelliag in the joiats, called rheumatism. His wife and three or four grown-up healthy children living. Present illness hegan four days hefore ndmission, with hcadache, general body pains, ligh fever, and diarrhcea.

Admitted to the hospital November 14, 1901 (hospital No. 2672).

Physical Examination. Medium-sized, spare mas, with dry, glazed tongue; teeth had, majority lost; pyorrhoa. Chalky deposit in the ears, knuckles, elhows, nad knees. Spleen much enlarged; rasping, systolic murmur at apex. Urine contaius albumin; acid; specific gravity, 1012; on microscopic examiantion, hyaline, light and dark grasular casts. Tro days after admisaion cosstantly complained of byperasthesia of the eatire bouly. No enlargement of the IJmphatic glands. All parts of the skia subjected to pressure have become much reddened, with here and there miaute punctate hemorrbages. Fever, which was high on admission, slightly reduced. Five days after admission right-sided pneumonin developed, with death in thirty-six hours.

The blood, examined day after admission: Erythrocytes, 2,731,250; leucocytes, 155,500; hrmoglohis, 60 per cent. Oa Novernher 19 th the leucocytes were 154,000 ; on the 20 th, 205,780 ; nad on the 21 st, 283,000 . Cultures from the circulating blood (November 21st) ebowed the preseace of the micrococcus lanceolntus. Differeatial count on November 16 th showed : Small mononuclears, 85.8 per cent.; polynuclears, 12 per cent.; large moanuclears, 1.6 per cent.; eosinophiles, 0.4 per 
cent. ; myelocytes, 0.2 per cent. Bacteriological examination of the gums showed isolated colonies of staphylococci. Examination of the stain films showed little change in the red cells; no poikilocytosis; nucleated cells not found. The small lymphocytes are present in great disproportion. The autopsy showed comparatively little enlargement of any Iymphatic glands; the spleen not enlarged ; interstitial nephritis, with fatty degeneration of the beart and lobar pneumonia. The examination of the hone-marrow showed the presence of large numbers of lymphocytes, with diminution in the inumer of polynuclear cells.

This case shows symptoms divergent from the chronic Iymphatic leukxemias, and resembles rather an acute infection in its onset. The duration of this man's illness was ahout eleven days. From the symptoms in recent cases one is atruck with the constricy of the presence of an ulcerative process in the gums and dry mouth (zerogtoma) in most of the eases; in others, hemorrhges or conditions akin to those seen in scurvy. The most of the cases recently reported have been stadied abroad, and perhaps the majority of them were in infasats and children.

In the acute cases the differential blood examination is apt to show more large mononuclear leucocytes than were present is this case. His other symptoms, horrever, are I think typical.

\title{
A CASE OF BANTI'S DISEASE, WITH DIFFUSE PRODUCTIVE NEPHRITIS.
}

\author{
By Cres W. Field, M.D., \\ OF NET YOR.
}

(From the Departmeut of Pathologs, Comell Unirersity 3Yedical Coliege.)

IT is the purpose of this paper to discuss $n$ peculiar and interesting pathological condition, exemplified in a cage of ndranced productive inflammation of the liver, spleen, and kidneys.

At the outset we are confronted by the difficulty of asgigning it to its proper position with complete certainty. There are four pathological conditions closely resembling each other, to three of which this case presents considerable similarity.

1. The condition which is known to the Italian authors as "Banti's cirrhosis" or " Banti's disease."

2. Cirrhosis of the liver, with secondary enlergement of the spleen. In a number of such cases there is also an anmmia of a secosdary character.

3. Splenic anæmia, in which we have a marked enlargement of the spleen and a pronounced secondary ansemis.

4. Primary splenomegaly of Bovaird (epitheliome primitive, Gaucher).

These conditions will be described with more detail in anotber portion of this paper. 